\title{
Reproductive biology of Echinometra lucunter (Echinodermata: Echinoidea) in a northeast Brazilian sandstone reef
}

\author{
EDUARDO J.B. LIMA ${ }^{1}$, PAULA B. GOMES ${ }^{2}$ and JOSÉ R.B. SOUZA ${ }^{1}$ \\ ${ }^{1}$ Departamento de Zoologia, Centro de Ciências Biológicas (CCB), Programa de Pós-Graduação em Ciências \\ Área de Biologia Animal, Universidade Federal de Pernambuco (UFPE), Av. Professor Moraes Rego, 1235 \\ 50670-420 Recife, PE, Brasil \\ ${ }^{2}$ Departamento de Biologia, Universidade Federal Rural de Pernambuco (UFRPE), Área de Ecologia \\ Rua Dom Manoel de Medeiros, s/n, 52171-900 Recife, PE, Brasil \\ Manuscript received on April 2, 2008; accepted for publication on July 22, 2008; \\ presented by ALEXANDER W.A. KELLNER
}

\begin{abstract}
The edible sea urchin Echinometra lucunter (Linnaeus, 1758) is a very common species on the sublittoral-midlittoral in Brazilian rocky shores. The aim of this work was to describe the gametogenesis and reproductive strategy of the $E$. lucunter population at Muro Alto beach in the Northeast coast of Brazil from August 2004 to August 2005. A total of 240 specimens were collected on the sandstone reef flat from a tidepool during spring low tides. The overall sex ratio was 1.12:1, without significant temporal variation except in October 2004. First sexual maturity occurred in individuals from a diameter of $20.8 \mathrm{~mm}$. There was not a significant difference in gonad index between females and males during the sampling period. The female's gonad index variation was associated with a well-defined spawning, corroborated by the histological analysis of the gonads, which demonstrates sex differences of the gamete production. By contrast, the males showed no clear pattern. It is suggested that continuous reproduction with seasonal peaks in the E. lucunter population occurs at Muro Alto beach.
\end{abstract}

Key words: beach rock, Brazil, Echinodermata, reproduction, sea urchin.

\section{INTRODUCTION}

Echinometra lucunter (Linnaeus, 1758) is a rock-boring species that feeds on algae and encrusting animals, and can be found in coastal waters up to $45 \mathrm{~m}$ deep (Tommasi 1966), often inhabiting burrows scraped with its spines and teeth on rocky substrata (Hendler et al. 1995). Its geographical distribution extends south from North Carolina (USA) and the Bermudas to Santa Catarina (Brazil), including the Caribbean and West Central America, and throughout East Africa (Bernasconi 1955, Tommasi 1966, Brito 1968, Hendler et al. 1995). It is the regular echinoid most commonly found on the coral reef formations in Pernambuco State (Brazil), and

Correspondence to: Eduardo J.B. Lima

E-mails: eduardojbl@yahoo.com.br/ejblima@hotmail.com is used as an indicator of the sublittoral-midlittoral edge (Fernandes et al. 2002).

High-density populations (12-100 urchins $\left./ \mathrm{m}^{2}\right)$ of $E$. lucunter have been implicated in reef damage at various locations; boring behavior alters the community's physical and biological structure (Hendler et al. 1995, Appana and Vuki 2003). Because of the density-dependent nature of the impact of urchins on some communities, knowledge of their life-history is essential for understanding the ecology of these interactions (Williamson and Steinberg 2002).

Several studies on the taxonomy and/or distribution of the E. lucunter have been made for the tropical Atlantic Ocean, such as Rathbun (1879), Bernasconi (1955), Tommasi (1966), Brito (1968), Lima-Verde 
(1969), Pompa et al. (1989), McGehee (1992), Hendler et al. (1995), Sewell and Young (1999), McCartney et al. (2000), Nodarse (2001), Sánchez-Jérez et al. (2001), and Fernandes et al. (2002). However, the information about gametogenic characteristics of the E. lucunter is incomplete regarding Brazilian populations.

Recently, Ventura et al. (2003) have mentioned ecological and reproductive aspects of the E. lucunter populations from Arraial do Cabo (rocky shore in Rio de Janeiro) and the Abrolhos archipelago (coral reef in Bahia). In addition, Tavares et al. (2004), have analyzed variation in biochemical composition of gonads in relation to the reproductive cycle from Galheta Island (rocky shores in Paraná). The aim of this work was to describe the gametogenesis and reproductive strategy of E. lucunter population at Muro Alto beach (Pernambuco State, Brazil) through histological examination of gonad development, and to estimate the gonad index, the sexual ratio and the size at the first sexual maturity.

\section{MATERIALS AND METHODS}

\section{STUdY Site}

The study was conducted at Muro Alto beach, on the southern coast of the state of Pernambuco (Lat $8^{\circ} 25.408^{\prime}$ to $8^{\circ} 25.598^{\prime} \mathrm{S}$; Long $34^{\circ} 58.398^{\prime}$ to $34^{\circ} 58.518^{\prime} \mathrm{W}$ ). This beach, which is about $2.5 \mathrm{~km}$ long, is protected by sandstone reefs (more than $1 \mathrm{~km}$ long) running parallel to the shore, building a shallow reef lagoon $(0.2-3 \mathrm{~m}$ deep) during low tides.

The regional climate is classified as As' by the Köppen system. The annual average air temperature is about $25^{\circ} \mathrm{C}$, with a variation in temperature less than $5^{\circ} \mathrm{C}$. The average rainfall is $2,000 \mathrm{~mm} / \mathrm{year}$, with a dry season (rainfall less than $100 \mathrm{~mm} /$ year) between September and February and a rainy season from March to August $(1,850 \mathrm{~mm} /$ year to $2,364 \mathrm{~mm} /$ year $)$. The seawater temperature varies from 27.2 to $29.1{ }^{\circ} \mathrm{C}$; and salinity, from 36.2 to 37.8 (Medeiros et al. 1999).

\section{Methods}

To investigate the reproductive strategy and gametogenesis of E. lucunter, 15 adult specimens ( $>33 \mathrm{~mm}$ in maximum diameter of the test) were collected monthly on the reef flat within the tidepool, which has an area of $6,480 \mathrm{~m}^{2}$, during spring low tides $(0.0$ to $0.3 \mathrm{~m})$, from August 2004 to August 2005. The temperature was taken with a dry-bulb thermometer (degrees Celsius), and salinity measured with a manual Refractometer.

The specimens were fixed via peristome with formaldehyde $4 \%$. Four measurements were taken from each animal, with a digital Caliper $(0.01 \mathrm{~mm}$ precision): maximum and minimum diameters of the test, test height, and Aristotle's lantern height. Next, the interradius gonad, which opens on the gonopore from the madreporite, was extracted and fixed with formaldehyde $10 \%$ for 72 hours, dehydrated in alcohol series, diaphanized in toluene and embedded in histological paraffin. Sections were made perpendicular to the axis of greatest length of the gonad at a thickness of $7 \mu \mathrm{m}$ cut from the middle portion of the blocks, and stained with haematoxylin-eosin (H.E.). The dissected test (spines + washed gut + Aristotle's lantern) and remaining gonads were put separately into a furnace at $120^{\circ} \mathrm{C}$ for 48 hours, after which the dry weight was assessed with a $10^{-4} \mathrm{~g}$ precision balance.

The classification of gametogenic development stages were modified from Tavares and Borzone (2006), which were described in results. The size at the onset of sexual maturity was estimated from the histological analysis of 45 specimens $(10-30 \mathrm{~mm}$ in maximum diameter of the test) collected in October 2004, during period of maximum maturity in the adult population.

The gonad index (GI) was calculated monthly, and expressed as a percentage: $\mathrm{GI}=$ [dry weight of 4 gonads/ dry weight of dissected test - (gonads + gut content)] $\times$ 100, modified from MacCord and Ventura (2004). The non-parametric Kruskal-Wallis test $(\mathrm{H})$ was used to compare the gonad index of sexes and throughout the year. Spearman's correlation coefficient $\left(r_{s}\right)$ was applied to establish the relationship between the gonad index and the morphological parameters (maximum and minimum diameters of the test, test height, and Aristotle's lantern height; $n=195$ ) for both sexes as gonad index for males and females were not significantly different. Chi-square test $\left(\chi^{2}\right)$ was used to test differences in the sex ratio (Siegel 1975). All analyses were done with BioEstat 3.0 software (Ayres et al. 2003), using a 5\% significance level. 


\section{RESULTS}

\section{ENVIRONMENTAL PARAMETERS}

The temperature of the tidepool water varied between $28^{\circ} \mathrm{C}$ (July-August 2005) and $37^{\circ} \mathrm{C}$ (April 2005); and the salinity, between 35 (June 2005) and 39 (NovemberDecember 2004, March-April 2005).

\section{SEX RATIO}

Of 195 adults specimens collected, 103 (52.82\%) were females and $92(47.18 \%)$ were males. The overall sex ratio in the population of E. lucunter was 1.12:1, without significant difference between sexes $\left(\chi^{2}=0.62 ; d f=\right.$ $1, \mathrm{p}=0.431)$. Furthermore, there was no significant variation from a sex ratio of 1:1 in monthly samples of urchins, except in October $2004\left(\chi^{2}=5.40 ; d f=1\right.$, $\mathrm{p}=0.020)$.

\section{Histology OF THE GonAdS}

Based on previous authors (Tavares and Borzone 2006), five stages were used to characterize the process of gametogenesis in E. lucunter:

Proliferative stage: gonad tubes were filled with nutritive phagocytes (storage cells), and small numbers of primary sex cells (oocytes in females, spermatocytes in males) were present along the tube wall. In females, the nutritive layer has attained its maximum thickness and oogonia were visible as intensely stained cells near the tube wall. In the early development of this stage, spermatocyte columns were sometimes observed in males, with a basophilic layer of spermatogonia and primary spermatocytes lining the tube wall. Few mature gametes (ova or spermatozoa) spermatozoa were found in the center of the tube among nutritive phagocytes.

Premature stage: the abundance of nutritive phagocytes decreased and the first mature gametes (ova or spermatozoa) began to accumulate in the lumen. $\mathrm{Nu}$ tritive phagocytes were closed between tube wall and lumen. In females, nutritive phagocytes occupied a peripheral position. In males, most of the columns of developing spermatocytes extended from the tube wall into the lumen. Spermatozoa accumulated within the lumen among the few remaining nutritive phagocytes.

Mature stage: most of the lumen was occupied by mature gametes, and nutritive phagocytes were reduced to a thin layer along the tube wall. In females, most of the ovarian lumen was filled by mature gametes with polygonal shape that exhibited a great of number of cortical granules at their surface. Few primary oocytes were found and nutritive phagocytes were located towards the periphery along the tube wall. In males, spermatozoa often appeared to swarm in strands. The tubes were filled with a dense mass of spermatozoa in the lumen. In some male gonads, a straight band of primary cells were still present but nutritive phagocytes were absent.

Depletion stage: the lumen was emptied as mature gametes were shed but not yet replaced to any great extent by nutritive phagocytes. In females, some relict oocytes/ova may be present in the lumen, where a layer of nutritive phagocytes began to grow. Besides, in males, there were many small spaces between the masses of spermatozoa and spermatocytes, as in the masses of spermatozoa.

Resting stage: the lumen of the tubes contained many nutritive phagocytes and unspawned residual ova/spermatozoa.

\section{Gametogenic Cycle}

Gametogenic development stages in females of E. lucunter were presented in Figure 1A. The proliferative stage was recorded briefly, focusing on the period between January and May 2005, when 9 to $18 \%$ of specimens showed immature sexual cells in their gonads. The premature stage was recorded only in May 2005 (44.5\%). However, from August to October 2004 the majority of females (60-92\%) were in the mature stage. Spawning started in early December 2004 and lasted until June 2005, with a peak from February to April $2005(72-100 \%)$. The resting stage was identified in all months, except February and April 2005.

The male cycle showed no annual temporal pattern (Fig. 1B). The depletion stage was recorded, except in May 2005, with high frequency value $(25-100 \%)$. On the other hand, the resting stage occurred in most months, with peaks in January, March and June 2005, when 50 to $75 \%$ of specimens displayed this stage.

\section{ONSET of SEXUal Maturity}

Most of the 45 specimens examined $(10-30 \mathrm{~mm}$ in maximum diameter) did not have ripe sex cells $(73 \%)$. 


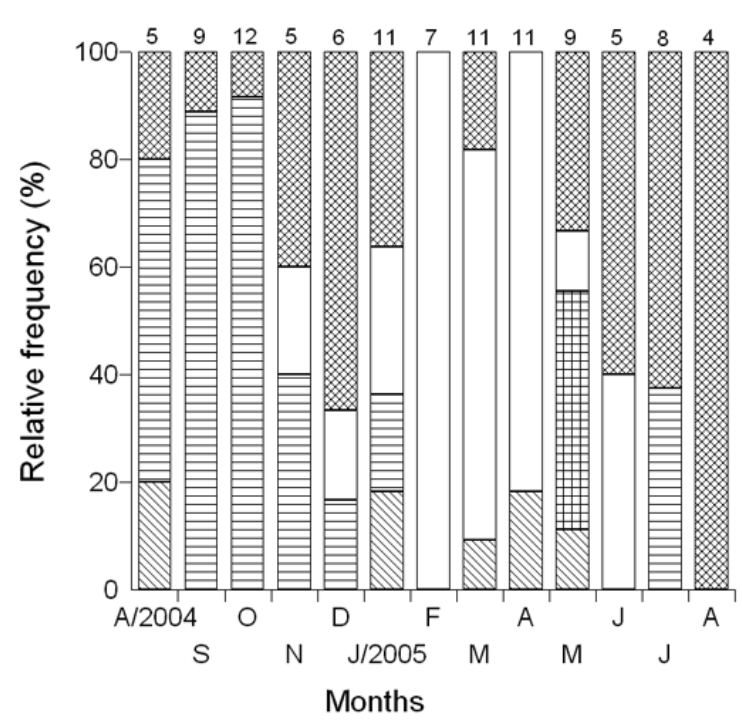

\section{A}

Resting

Depletion

Mature

田 Premature

Proliferative

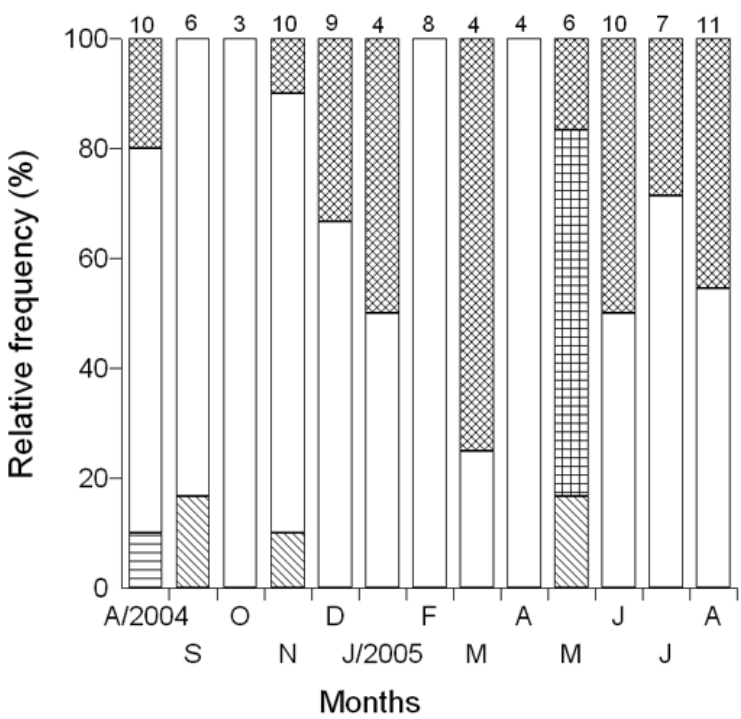

B

Resting

Depletion

目 Mature

田 Premature

Proliferative

Fig. 1 - Monthly variation of the relative frequency (\%) of each gametogenic development stage of Echinometra lucunter during the sampling period at Muro Alto beach, Pernambuco, Brazil.

(A) Females; (B) Males. Values indicate the total number of specimens analyzed per month.

Ripe sex cells were absent from all males of E. lucunter smaller than $20.8 \mathrm{~mm}$ and from all females smaller than $21.4 \mathrm{~mm}$.

\section{GONAD INDEX}

In the both sexes GI average changed synchronously in a well-defined annual pattern, reaching maximum values in dry season (September to October 2004), decreasing from the beginning of rainy season (March 2005), and rising again in late rainy season (August 2005) (Fig. 2). The gonad index of females was not significantly dif- ferent from males, during the sampling period at Muro Alto beach $(\mathrm{H}=0.02 ; d f=1 ; \mathrm{p}=0.898)$. But the monthly variation of GI for females and males was significant $(\mathrm{H}=72.93 ; \mathrm{H}=65.75 ; d f=12 ; \mathrm{p}<0.0001$, respectively).

In relation to gametogenic development stages, the highest female GI values were found in the mature stage $(3.72 \%)$, and the lowest value was found in the depletion stage (1.18\%). The males' GI values presented a lower range, from $1.49 \%$ in resting stage to $2.72 \%$ in proliferative stage (Fig. 3). 


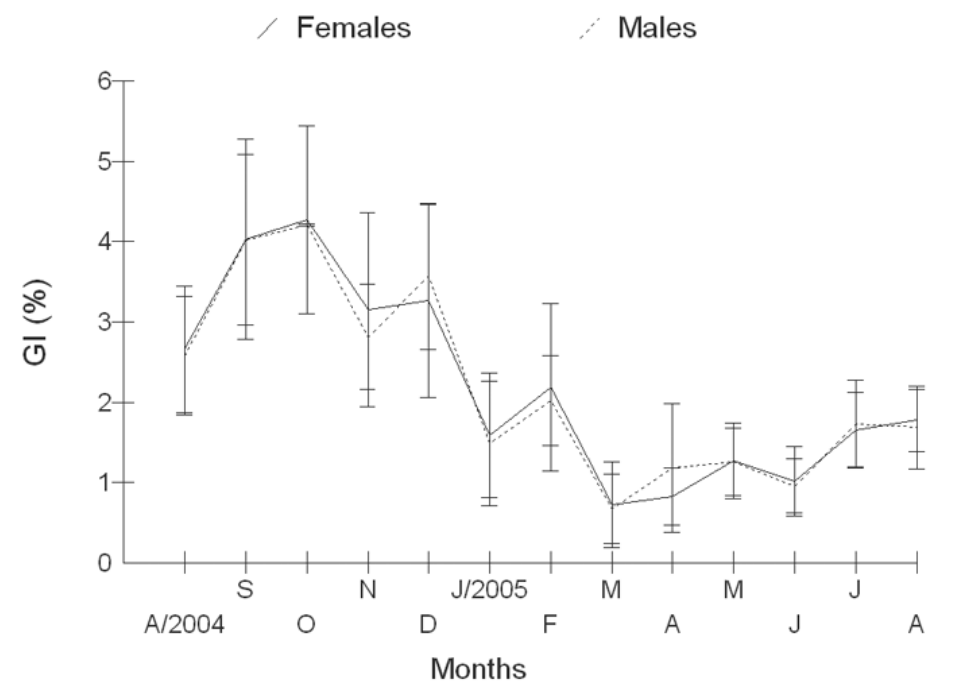

Fig. 2 - Monthly variation of the mean gonad index (GI) of Echinometra lucunter for both females and males during the sampling period at Muro Alto beach, Pernambuco, Brazil (Vertical bars indicate: $\pm \mathrm{SD}$, standard deviation).

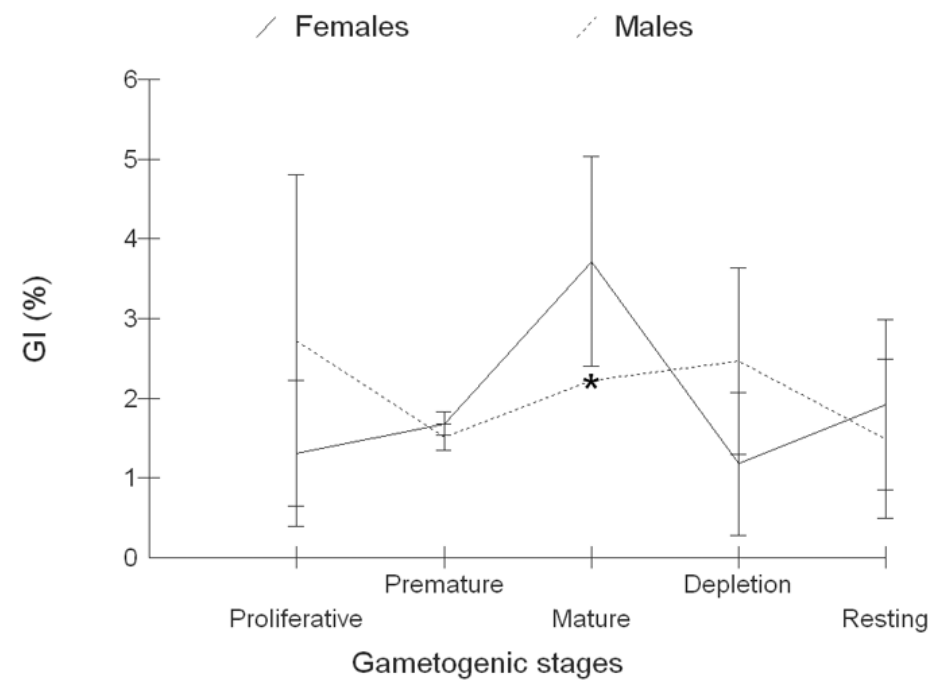

Fig. 3 - Mean gonad index (GI) of Echinometra lucunter for both females and males in different gametogenic development stages at Muro Alto beach, Pernambuco, Brazil (Vertical bars indicate: $\pm \mathrm{SD}$, standard deviation). $(*)$ a single specimen.

Spearman's correlation, based on a sample of 195 urchins, showed relatively low correlation coefficients between GI and morphological parameters at Muro Alto beach (Table I).

\section{DISCUSSION}

Echinometra lucunter presented a marked reproductive cycle in the local population as in some other regions and other regular echinoid populations (McPherson
1969, Crapp and Willis 1975, Lessios 1981, Cameron 1986, Lessios 1991, Lamare et al. 2002, Tavares et al. 2004). There was an equal sex ratio and no significant differences between male and female gonad indices. The gametogenic cycle of females was annual, and the cellular processes during gametogenesis between males and females were asynchronous.

The overall sex ratio of $E$. lucunter did not differ from other gonochoric species of echinoids (Crapp and 


\section{TABLE I}

Spearman's correlation coefficient between gonad index (GI) and morphological parameters of Echinometra lucunter at Muro Alto beach, Pernambuco, Brazil, August 2004 to August 2005.

\begin{tabular}{c|c|c|c}
\hline Parameters & $\mathrm{r}_{\mathrm{s}}$ & $\mathrm{p}$ & $\mathrm{n}$ \\
\hline $\begin{array}{c}\text { Maximum diameter } \\
\text { of the test } \times \text { GI }\end{array}$ & -0.254 & 0.0003 & 195 \\
\hline $\begin{array}{c}\text { Minimum diameter } \\
\text { of the test } \times \text { GI }\end{array}$ & -0.315 & 0.0001 & 195 \\
\hline Test height $\times$ GI & -0.199 & 0.0053 & 195 \\
\hline $\begin{array}{c}\text { Aristotle's lantern } \\
\text { height } \times \text { GI }\end{array}$ & -0.319 & 0.0001 & 195 \\
\hline
\end{tabular}

$\mathrm{GI}=$ gonad index $; \mathrm{r}_{\mathrm{S}}=$ Spearman's correlation coefficient; $\mathrm{p}=$ probability; $\mathrm{n}=$ number

Willis 1975, Williamson and Steinberg 2002). In fact sex ratio estimated for $E$. lucunter at contrasting habitats was not significantly different for two Brazilian populations: sandstone reef at Muro Alto beach (this study) and rocky shores on the Galheta Island, on the southern coast of Brazil (Y.A.G. Tavares, unpublished data). Besides the overall 1:1 sex ratio, the great variability in the monthly sex ratio suggests that the individuals would be randomly distributed, and a higher monthly sample is advisable.

The population of E. lucunter, at Muro Alto, showed one spawning period at the dry season (October 2004 to February 2005). However, the reproduction data was obtained for a single year and this does not justify the assumption of gametogenesis cycle. Other populations of $E$. lucunter presented one or two periods of spawning. In agreement with this, in Barbados (West Indies) E. lucunter differed in their periodicity, spawning occurring once a year in high wave-energy habitats and twice a year in low-wave habitats (Lewis and Storey 1984). On the other hand, the Caribbean echinoid population of E. lucunter exhibits mixed patterns of reproductive periodicity. E. lucunter in Fort Randolph (Panama) reaches a peak of gonad content in October, probably spawns until December, and starts building up its gonads subsequent to that. There may be a secondary spawning right after March. In Maria Chiquita (Panama), on the other hand, if there is a seasonal trend, it is much less pronounced (Lessios 1981). This species is also reported to spawn between August and October, in Puerto Rico (Cameron 1986), and to attain a peak in gonad index during June and July, in Florida Keys (McPherson 1969).

Ventura et al. (2003) also found significant geographical variation in the gametogenic stages in E. lucunter populations on two Brazilian habitats, suggesting that spawning time may be longer in populations from coral reef than in those on the rocky shore. In a southern Brazilian beach, the spawning period of E. lucunter occurred during October and November (Tavares et al. 2004).

Temperate echinoids species present an annual reproductive cycle. In New Zealand, the sea urchin Evechinus chloroticus (Valenciennes, 1846) spawned in early summer (Lamare et al. 2002). On the Coast of Scotland, Echinus esculentus Linnaeus, 1758 spawned in summer (Kelly et al. 2001). The periodicity in the reproductive cycle of echinoids changes latitudinally and locally (Lessios 1981). This suggests that other factors such as food and hydrodynamics influence the gametogenic cycle (Bauer 1976, Lessios 1991, Lamare et al. 2002, Ventura et al. 2003, Sellem and Guillou 2007).

Different gametogenic development stages were found between females and males suggesting a reproductive asynchrony in E. lucunter. This asynchrony had been observed in other regular echinoids of continuous reproduction, such as Echinometra mathaei (Blainville, 1825) and Lytechinus variegatus (Lamarck, 1816) (Pearse and Phillips 1968, A.O.R. Junqueira, unpublished data). However, according to Lima et al. (2006), if the spawning occurs over the entire year, with variation in the monthly frequency of reproducing females and conspicuous periods of higher reproductive activity, then continuous reproduction with seasonal peaks may be applied. In the same manner, $E$. lucunter females and males probably do not release all of their gametes at once. Males presented many gaps in the mass of spermatozoa (depletion stage) that were observed in all months (except May 2005), indicating that spermatogenesis appears to occur faster than oogenesis, as observed by MacCord and Ventura (2004) with Cassidulus mitis Krau, 1954. 
The first sexual maturity of $E$. lucunter occurred in individuals with a diameter of at least $20 \mathrm{~mm}$. McPherson (1969) found also different sizes at sexual maturity in two species of Echinometra: E. lucunter males reaching maturity from $18 \mathrm{~mm}$ and females from $21 \mathrm{~mm}$ in diameter, whereas in E. viridis Agassiz, 1863 maturity was reached in individuals from about $15 \mathrm{~mm}$ diameter for both sexes.

Gametogenesis and intra-gonadal nutrient storage are linked in sea urchin reproduction (Walker et al. 2006). The E. lucunter's GI displayed two contrasting results: males and females presented the same variation in GI, but only females showed a synchrony between GI and the gametogenic development stages. E. lucunter's females seem to need a certain amount of energy for oogenesis. Thus, the allocation of resources, energy, and materials for growth, reproduction, or maintenance probably differ for both sexes. Starr et al. (1993) found that the phytoplankton abundance may also modulate the onset of spawning in echinoids. Indeed, the area presents a high quantity of material suspended at the mouth of the estuary, adjacent to Muro Alto beach that is influenced by rainfall (which has a seasonal variation) and tides, causing an increasing variation in phytoplanktonic production (Koening et al. 2003). Harmelin et al. (1981) associated the high density of echinoids to a large nutrient availability on the French Mediterranean coast, as a consequence of domestic pollution. Finally, the asynchrony of E. lucunter between males and females depends on the seasonality of resources.

On the other hand, the larger spawning for males at Muro Alto beach show that release of spermatozoa triggers oocytes' release. Levitan (2005) reported that generally males spawn before females. For this author, a hypothesis to explain this is that sperm are the cue for females to release eggs. The triggering mechanism was observed by Starr et al. (1990, 1992), in some species, including sea urchins. Besides, sex differences in spawning timing of marine invertebrates can be explained on the basis of the differential costs and benefits of spawning out of synchrony with the other sex (Levitan 2005).

\section{ACKNOWLEDGMENTS}

We thank to Fábia Lira and Elisângela Dias of the Aggeu Magalhães Research Center (CPqAM/Fiocruz-
PE) for their assistance in the laboratory work for the histological procedures. We wish to thank two anonymous referees for suggestion and grammatical revision.

\section{RESUMO}

O ouriço-do-mar comestível Echinometra lucunter (Linnaeus, 1758) é uma espécie muito comum no infralitoral e mediolitoral do Brasil. O objetivo deste trabalho foi descrever a gametogênese e a estratégia reprodutiva da população de $E$. lucunter na praia de Muro Alto entre agosto de 2004 e agosto de 2005. Um total de 240 espécimes foi capturado de uma poça de maré situada no topo recifal, durante as marés baixas de sizígia. A razão sexual total foi de 1,12:1 sem variação temporal significativa, exceto em outubro de 2004. A primeira maturidade sexual ocorreu em indivíduos a partir de 20,8 mm de diâmetro. Não houve nenhuma diferença significativa no índice gonadal entre fêmeas e machos durante o período de amostragem. A variação do índice gonadal das fêmeas foi associada a um período de desova bem definido, corroborado pela análise histológica das gônadas, que demonstra diferenças sexuais na produção de gametas. Ao contrário, os machos não apresentaram nenhum padrão. Sugere-se que a reprodução da população de E. lucunter na praia de Muro Alto é contínua, com picos sazonais.

Palavras-chave: recife de arenito, Brasil, Echinodermata, reprodução, ouriço-do-mar.

\section{REFERENCES}

Ayres M, Ayres Jr M, Ayres DL and Santos AS. 2003. BioEstat 3.0, Belém: Sociedade Civil Mamirauá, MCT - CNPq, 292 p.

APPANA SD AND VUKI VC. 2003. A novel method of assessing bioerosion by the sea urchin Echinometra sp. A on a Fijian reef. S Pac J Nat Sci 21: 25-30.

BAUER JC. 1976. Growth, aggregation, and maturation in the echinoid, Diadema antillarum. Bull Mar Sci 21: 25-30.

BERNASCONI I. 1955. Equinoideos y Asteroideos de la colección del Instituto Oceanográfico de la Universidad de San Pablo (Primera contribución). Bolm Inst oceanogr S Paulo 6 (1-2): 51-77.

BRITO IM. 1968. Asteróides e equinóides do Estado da Guanabara e adjacências. Bolm Mus Nac, Sér Zool 260: $1-51$.

CAMERON RA. 1986. Reproduction, larval occurrence and recruitment in Caribbean sea urchins. Bull Mar Sci 39: $332-346$. 
CRAPP GB AND WILlis ME. 1975. Age determination in the sea urchin Paracentrotus lividus (Lamarck), with notes on the reproductive cycle. J Exp Mar Biol Ecol 20: $157-178$.

Fernandes MLB, Tommasi LR AND Lima EJB. 2002. Filo Echinodermata de Pernambuco. In: TABARELli M AND SILVA JMC (Eds), Diagnóstico da biodiversidade de Pernambuco, Recife: Editora Massangana, Recife, Brazil, p. 405-427.

HARMELIN J-G, Bouchon C AND Hong J-S. 1981. Impact de la pollution sur la distribution des échinodermes des substrats durs en Provence (Méditerranée Nord-Occidentale). Téthys 10: 13-36.

Hendler G, Miller Je, Pawson Dl and Kier PM. 1995. Class Echinoidea: sea urchins, sand dollars, and heart urchins. In: Hendler G ET AL. (Eds), Sea stars, sea urchins, and allies: echinoderms of Florida and the Caribbean, Washington: Smithsonian Institution Press, Washington, USA, p. 197-249.

Kelly MS, OWen PV and Pantazis P. 2001. The commercial potential of the common sea urchin Echinus esculentus from the west coast of Scotland. Hydrobiologia 465: 85-94.

Koening ML, LeÇa EE, Neumann-Leitão S AND MACÊDO SJ. 2003. Impacts of construction of the Port of Suape on Phytoplankton in the Ipojuca River Estuary (Pernambuco-Brazil). Braz Arch Biol Techn 46: 73-81.

LAMARE MD, Brewin PE, BARKER MF AND WING SR. 2002. Reproduction of the sea urchin Evechinus chloroticus (Echinodermata: Echinoidea) in a New Zealand fiord. NZ J Mar Freshw Res 36: 719-732.

LEVITAN DR. 2005. Sex-specific spawning behavior and its consequences in an external fertilizer. Am Nat 165: 682-694.

LESSIOS HA. 1981. Reproductive periodicity of the echinoids Diadema and Echinometra on the two coasts of Panama. J Exp Mar Biol Ecol 50: 47-61.

Lessios HA. 1991. Presence and absence of monthly reproductive rhythms among eight Caribbean echinoids off the coast of Panama. J Exp Mar Biol Ecol 153: 27-47.

LEWIS JB AND STOREy GS. 1984. Differences in morphology and life history traits of the echinoid Echinometra lucunter from different habitats. Mar Ecol Prog Ser 15: 207-211.

Lima GV, SOARes MRS AND OShIRO LMY. 2006. Reproductive biology of the sesarmid crab Armases rubripes
(Decapoda, Brachyura) from an estuarine area of the Sahy River, Sepetiba Bay, Rio de Janeiro, Brazil. Iheringia, Sér Zool 96: 47-52.

LIMA-VERDE JS. 1969. Primeira contribuição ao inventário dos equinodermas do nordeste brasileiro. Arq Est Biol Mar 9: 9-13.

MacCord FS And Ventura CRR. 2004. Reproductive cycle of the endemic cassiduloid Cassidulus mitis (Echinoidea: Cassiduloida) on the Brazilian coast. Mar Biol 145: 603-612.

McCartney MA, Keller G and Lessios HA. 2000. Dispersal barriers in tropical oceans and speciation in Atlantic and eastern Pacific sea urchins of the genus Echinometra. Mol Ecol 9: 1391-1400.

MCGEHEE MA. 1992. Distribution and abundance of two species of Echinometra (Echinoidea) on coral reefs near Puerto Rico. Caribb J Sci 28 (3-4): 173-183.

MCPherson BF. 1969. Studies on the biology of the tropical sea urchins, Echinometra lucunter and Echinometra viridis. Bull Mar Sci 19: 194-213.

Medeiros C, Macêdo SJ, Feitosa FAN And Koening ML. 1999. Hydrography and phytoplankton biomass and abundance of North-East Brazilian waters. Arch Fish Mar Res 47 (2-3): 133-151.

NoDARSE A. 2001. Abundancia y distribución del erizo Echinometra lucunter (Linnaeus) (Echinodermata, Echinoidea) en un arrecife del litoral norte de ciudad de La Habana. Rev Invest Mar 22: 107-115.

PeARse JS AND Phillips BF. 1968. Continuous reproduction in the Indo-Pacific sea urchin Echinometra mathaei at Rottnest Island, Western Australia. J Mar Freshw Res 19: 161-172.

Pompa L, Prieto AS And Manrique R. 1989. Abundancia y distribución espacial en una población del erizo Echinometra lucunter (L) en el Golfo de Cariaco, Venezuela. Acta Cient Venez 40: 289-294.

RAThbun R. 1879. A List of the Brazilian Echinoderms, with Notes on their Distribution, etc. Trans Conn Acad 5: 139-158.

SÁnchez-Jérez P, Cesar A, Cortez FS, Pereira CDS AND SILVA SLR. 2001. Distribución espacial de las poblaciones de erizos más abundantes de la costa sudeste del litoral de São Paulo (Brasil). Cienc Mar 27: 139-153.

Sellem F And Guillou M. 2007. Reproductive biology of Paracentrotus lividus (Echinodermata: Echinoidea) in two contrasting habitats of northern Tunisia (south-east Mediterranean). J Mar Biol Ass UK 87: 763-767. 
SEwell MA AND Young CM. 1999. Temperature limits to fertilization and early development in the tropical sea urchin Echinometra lucunter. J Exp Mar Biol Ecol 236: 291-305.

SIEGEL S. 1975. Estatística não-paramétrica para as ciências do comportamento, São Paulo: McGraw-Hill do Brasil, $350 \mathrm{p}$.

Starr M, Himmelman JH and Therriault J-C. 1990. Direct coupling of marine invertebrate spawning with phytoplankton blooms. Science 247: 1071-1074.

Starr M, Himmelman JH And Therriault J-C. 1992. Isolation and properties of a substance from the diatom Phaeodactylum tricornutum which induces spawning in the sea urchin Strongylocentrotus droebachiensis. Mar Ecol Prog Ser 79: 275-287.

Starr M, Himmelman JH And Therriault J-C. 1993. Environmental control of green sea urchin, Strongylocentrotus droebachiensis, spawning in the St. Lawrence Estuary. Can J Fish Aquat Sci 50: 894-901.

Tavares YAG, Kawall HG and Borzone CA. 2004. Biochemical changes the gonad in relation to the reproductive cycle of Echinometra lucunter and Arbacia lixula in southern Brazil. In: LAWRENCE JM AND GuzMan O (Eds), Sea-Urchin Fisheries and Aquaculture: proceedings of the International Conference on SeaUrchin Fisheries and Aquaculture, Puerto Varas, March 2003. DEStech Publications Inc., Lancaster, Pensylvania, p. 147-155.
TAVAres YAG AND Borzone CA. 2006. Reproductive cycle of Mellita quinquiesperforata (Leske) (Echinodermata, Echinoidea) in two contrasting beach environments. Rev Bras Zool 23: 573-580.

TOMMASI LR. 1966. Lista dos equinóides recentes do Brasil. Contrções Inst oceanogr Univ S Paulo, Sér Ocean Biol 11: $1-50$

Ventura CRR, Varotto RS, Carvalho AlPS, PereiRA AD, Alves SLS AND MACCORd FS. 2003. Interpopulation comparison of the reproductive and morphological traits of Echinometra lucunter (Echinodermata: Echinoidea) from two different habitats on Brazilian coast. In: FÉRAL J-P AND DAVID B (Eds), Echinoderm Research 2001: proceedings of the $6^{\text {th }}$ European Conference on Echinoderm Research, Banyuls-sur-mer, September 2001. Swets and Zeitlinger, Lisse, Netherlands, p. 289-293.

WALKer CW, Unuma T AND Lesser MP. 2006. Gametogenesis and Reproduction of Sea Urchins. In: LAWRENCE JM (Ed.), Edible sea urchins: biology and ecology (developments in aquaculture and fisheries science, volume 37, $2^{\text {nd }}$ ed., Amsterdam: Elsevier, p. 11-34.

Williamson JE AND Steinberg PD. 2002. Reproductive cycle of the sea urchin Holopneustes purpurascens (Temnopleuridae: Echinodermata). Mar Biol 140: $519-532$. 